\title{
Creation of Sustainable Learning Environments in South African Rural Schools: A Call for Effective Implementation of ICTs
}

\author{
Jogymol Kalariparampil Alex \\ Faculty of Educational Sciences, Walter Sisulu University, Eastern Cape, South Africa
}

Received March 21, 2021; Revised May 8, 2021; Accepted June 6, 2021

\section{Cite This Paper in the following Citation Styles}

(a): [1] Jogymol Kalariparampil Alex, "Creation of Sustainable Learning Environments in South African Rural Schools: A Call for Effective Implementation of ICTs," Universal Journal of Educational Research, Vol. 9, No. 7, pp. 1430 - 1438, 2021. DOI: 10.13189/ujer.2021.090709.

(b): Jogymol Kalariparampil Alex (2021). Creation of Sustainable Learning Environments in South African Rural Schools: A Call for Effective Implementation of ICTs. Universal Journal of Educational Research, 9(7), 1430 - 1438. DOI: 10.13189/ujer.2021.090709.

Copyright $\subseteq 2021$ by authors, all rights reserved. Authors agree that this article remains permanently open access under the terms of the Creative Commons Attribution License 4.0 International License

\begin{abstract}
Information and Communication Technologies (ICTs) are the core of the digital economy and could be important catalysts for progress on the Sustainable Development Goals (SDGs), which can improve people's lives. The 2030 Agenda for Sustainable Development recognises the great potential of global connectivity to accelerate human progress. ICT has become an integral part of educational development as it enhances the efficiency and productivity of both teaching and learning of any subject. Though remarkable progress has been made in terms of access to ICT integrated education in South Africa, the issue of its reaching every rural school student and teacher has not been resolved. Against this backdrop, this paper looks at learning environments and the use of ICTs in rural schools in the Eastern Cape, a rural South African province, through an empirical quantitative study; and calls for creating sustainable learning environments through the effective implementation and use of ICTs. Data on the learning environments in Eastern Cape schools were collected from three different sources. A sample of university students and school teachers provided information on the ICT environment in schools. Government reports on ICT integrated teaching that shed light on the vision and planning of the creation of sustainable learning environments in rural education contexts, were also analysed. It is concluded that computer access and other forms of technology have dramatically increased in South
\end{abstract}

Africa, however, the level of classroom utilization of technology does not correlate with this significant rise in rural schools. This calls for audacious investments to be accomplished in two major aspects: networking the classrooms with internet facilities and equipping the teachers with ICT implementation in the classrooms. Only then can sustainable learning environments in the rural schools be comprehended in the context of the Fourth Industrial Revolution (4IR) in South Africa.

Keywords ICTs in Education, Sustainable Development, Rural Schools

\section{Introduction}

In the era of globalization, education is regarded as one of the most critical factors for maintaining competitiveness and development. Countries all over the world are working to modernize their education and training systems in order to keep up with the digital economy and society [1]. Education has long served as a great leveler of opportunity around the world, in every region, because it not only makes people realize their potential, but also contributes to their communities and the world. Good education increases awareness, stimulates creativity, fosters the development of skills that drive growth and prosperity, and promotes the 
development of inclusive communities [2]. Education has a vital part in crafting a fair and just society, constructing robust communities and developing the knowledge-based economy [3]. Since attaining quality education offers the foundation for refining people's lives and contributes to sustainable development [2], new sustainable learning environments, with increased flexibility that connect school, home and community learning, and support learning outside the boundaries of learning spaces and beyond the conservative learning time, is required [3]. The Government Gazette No. 26734 on e-education [4] asserts that education systems have an obligation to deliver on public expectations of quality education for economic growth and social development.

This can be achieved through the integration of Information and Communication Technologies (ICTs) in teaching and learning as the livelihoods of billions of people linked by mobile devices, with excellent processing power, stowage capacity, and access to knowledge, are limitless in our present times [5]. ICT is important in education as a way of supporting a teaching and learning process, and it is best used in the provision of a value development process [6]. This is confirmed by Noor-Ul-Amin [7] that the adoption and use of ICTs in education have a positive impact on teaching, learning and research, and Yusuf [8] notes that ICTs in education will invent, accelerate, enrich, deepen skills, empower and engage students; link school experiences to work practices; build economic viability for tomorrow's jobs; enhance teaching and assist schools in change. Linking of the curriculum with national goals, infrastructure development, physical resources, processes of equipment purchase, human resource allocation, relevance of pre-service and in-service teacher training programs, trainers, advisors and guidelines from professionals, funding and financial monitoring, policy and guidelines, software, maintenance, monitoring and evaluation, and sustainability are the key ingredients required for sustainable quality ICT education to suit any country [9]. ICTs have enormous potential for information dissemination, productive learning, and the advancement of more efficient education systems. They can also help to drive educational progress while also address global energy, environmental, and social challenges [10].

Elseragy et al. [3] discuss the situation in Egypt, where the increase in the number of students enrolled in educational institutions, primarily schools in the traditional sense, has been both encouraging and challenging. Issues like high numbers in the classrooms, a long and obligatory educational span of nine years, multiple schooling shifts, the non-existence of schools in many regions, and the fading condition of the current school structures, have necessitated an imperative for probing new means and notions of schools. This required the raising of the educational standard as one of the urgencies of the government. In Europe also, the ICT's position as a key enabler of innovation and creativity in learning in general, and in education and training in particular, is recognized by policymakers and educational stakeholders [1]. However, it should be noted that the full potential of ICT is not being realized in formal education; and major questions about the long-term viability, influence, costs, and mainstreaming of ICT-enabled learning initiatives are being raised in Europe [1]. A similar situation is faced by the South African Government in the post-apartheid era. South Africa has made remarkable progress in the transition from apartheid to democracy, establishing the institutions necessary for a stable and transformative country [11]. In this regard, 26 years into democracy, South Africa has achieved great strides in improving infrastructure, school nutrition programmes and resources allocation to most of its rural learning environments. However, to maintain this momentum and to achieve sustainability, these learning environments need to realise the necessity to integrate ICT into learning. Since ICT has the potential to access information, it will be a feasible tool in decreasing the urban-rural divide and addressing the needs that arise through globalization since it provides the means to achieve a sustainable lifestyle based on respect for human values and concern for limited resources [9].

In the same vein, in the context of the Fourth Industrial Revolution (4IR), Oke, Araujo, and Fernandes [12] opine that the education sector, especially in Africa, is unprepared for the 4IR, though there are signs of opportunities to capitalize on the much-anticipated 4IR potential. Oke, Araujo, and Fernandes [12] believe that although 4IR can help students learn more effectively and transform the workplace, there is a need to examine the learning environment and consider the facilitators and obstacles to 4IR diffusion.

Against this backdrop, this paper aims to investigate whether Eastern Cape schools are in the path of sustainable development through the creation of sustainable learning environments to face the 4IR. This is achieved through finding the answers to the research questions:

a) What type of learning environments is available in the schools in Eastern Cape (A rural Province)?

b) Are these learning environments ready with ICT implementation for sustainability?

This paper is built on the key concept of sustainable development and framed on the theoretical perspectives of ICT integrated classrooms as sustainable learning environments, which are explained below.

\subsection{Sustainable Development}

According to the World Commission on Environment and Development [13] and also cited in Sustainable Development [14], sustainable development refers to development that satisfies current needs without jeopardizing future generations' ability to fulfill their own. Sachs [15] posits that sustainable development is both an 
analytical and normative approach, the systematizing code for meeting social development goals concurrently nourishing the ability of natural systems to provide the natural resources and ecosystem services of the economy and society. Sustainable development consists of three main pillars: economic growth, environmental protection, and social equality/inclusion [13]. Goal \#4 of Sustainable Development refers to safeguarding inclusive and quality education for all and encourage enduring learning. Some of the objectives of the National Development Plan (NDP) 2030 relate to raising employment through faster economic growth, improving the quality of education, and improving skills development and innovation [11] (p.17). It follows, therefore, that education is the key that allows many other Sustainable Development Goals (SDGs) as the cycle of poverty can be broken through quality education [11] and, the learning environments in the schools need to be developed for sustainability.

\subsection{ICT Integrated Classrooms as Sustainable Learning Environments}

Learning spaces are multifaceted spaces where collective skills, knowledge and practices of a nation are trained, molded, stimulated, and communicated [3]. A learning environment is composed of teachers, students, and the physical environment. Supporters of student-centered curriculum argue that the curriculum ought to have combined with physical environment as it guides learning and it should be well organised to nurture learning prospects [16]. School buildings also need to support and be sensitive to the educational needs of the 21 st century education environments which promote learning through active investigation, social interaction and collaboration, and further, to support a full range of learning and teaching strategies from direct explicit instruction to virtual connection and communication. In response to the question of whether the physical environment has an effect on learning environments, Lippman [17] asserts that a responsive design approach will assist designers in creating more creative and sustainable learning environments that are responsive to the needs of 21st-century education. Learning environments in the 21 st century is imagined as places where learners participate in self-directed and cooperative learning practices, and the physical environment is designed to be reorganized on a regular basis to facilitate learning [17]. Therefore, constructivist ideas from the 20th century, which see the learner as active and the learning environment as passive, should be replaced with a new viewpoint [17]. Learners are likely to be motivated to expand their growth beyond their current level of understanding if technology is completely integrated into the learning process. Learning environments of the future are to be based on the integration of ICTs. According to Oke, Araujo and Fernandes [12]; the digital technology that underpins 4IR goes beyond computers and e-materials, it must be consistent with a learner-centered approach in order to be successful in improving students' learning experiences.

Agreeably, school buildings have a vital role in raising educational standards [3], but the 21 st century learning environments are expected to use ICTs to promote learning and development (Vygotsky, 1978, cited in Elseragy, Elnokaly, and Gabr [3]. Learner-centered values necessitate educators to advance or prepare school curriculum that inspires students to explore their learning environments through self-directed and "cooperative" learning experiences in order to nurture learning prospects. This is a novel approach to incorporating topics like technology into learning in contemporary education [16]. Learning environments are to be programmed, planned, and designed for the provisioning of the envisioned learning activities [17]. Poor school and classroom design can negatively impact student achievement by disrupting focus, innovation, and overall well-being [3]. The consistency of such learning environments has a significant impact on whether students learn better or worse. The classroom is the fundamental entity of the scholastic environment for a learner and his bodily and emotional well-being [3]. Methodologies to instruction in scholastic settings are shifting in that innovative teaching methods and curricula, changes in student populations and information technology, are all re-shaping learning in essential means [3]. Thus, integration of ICTs is one way to create sustainable environments that support learning. In this context, with regard to South Africa, this paper proposes sustainable learning environment as ICT integrated classrooms which promotes more active learning and effective teaching.

Several urban schools in South Africa have fully integrated ICT, but the same cannot be said for rural schools, which is unfortunate. As a result, a 'digital divide' has emerged between rural and urban schools [18]. In this context, it is worth exploring what type of learning environment is available and whether these learning environments are ready with ICT implementation in the rural schools in Eastern Cape.

\section{Materials and Methods}

The study used a positivist paradigm and quantitative approach to collect data from different sources. Part of the data originated from a major study that was conducted in a rural South African university. It is the practice, by the author of this paper, that every year the first-year mathematics education students are to give an idea of the schools from which they came in order to attend to the different needs of the students. Data on the learning environments in Eastern Cape schools were collected from a voluntary sample of 173 first year mathematics education students from which the information of 127 schools (some of the students were from the same schools) 
was collected through a Likert scale questionnaire. Students were asked to comment on the school and classroom conditions and the support they received when they were at the schools. In-classroom use of ICTs for learning and teaching was also an item in the questionnaire. Data Sources such as 'Quality Education, why it Matters' by UNICEF [2]; 'National Development Plan 2030; Our Future-make it Work' by the National Planning Commission [11]; and 'The State of ICT in Education in South Africa' published by the National Education Collaboration Trust (NECT) Technical Report of 2016 on rural schools and ICT integrated teaching; were analysed as they are authentic reports that shed light on the vision and planning of the creation of sustainable learning environments in rural education contexts. An anonymous survey data from 21 rural school teachers from an ICT workshop conducted in the rural university also contributed to the data for the study. The rural school teachers who voluntarily took part in the study, agreed to use the data for presentation and possible article publication. All the ethical requirements were met. The two sets of data from the students and the teachers contributed to the overall picture of the learning environment and the use of ICTs in the rural schools in Eastern Cape.

\subsection{Results}

Data from the different sources were analysed separately and are shown below.

\subsubsection{Analysis of the data from the students' questionnaire}

Data from the students' questionnaire were analysed using Microsoft Excel 2013. Figures 1 and 2 give information on the first research question on the type of learning environments available in the Eastern Cape schools and Figure 3 gives answers to the second research question on the readiness of the above learning environments with ICT implementation for sustainability. Figure 1 shows the school and classroom conditions in 127 Eastern Cape rural schools.

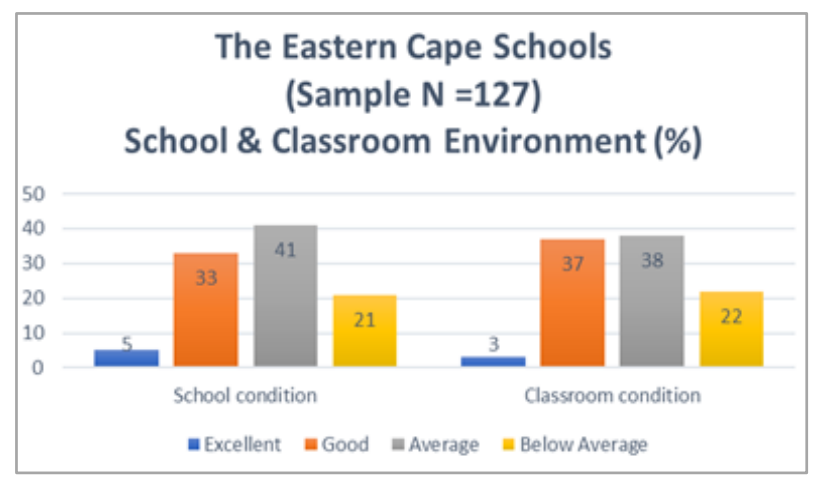

Figure 1. School and Classroom Environment of 127 Eastern Cape Schools as per students' response
Figure 1 shows that only 5\% schools in the sample have excellent and $33 \%$ have good conditions, whereas $41 \%$ schools are of average conditions and $21 \%$ schools have below average conditions. It is also to be noted that only $3 \%$ have excellent classroom environments and $37 \%$ have good classroom environments, $38 \%$ have average and $22 \%$ have below average classroom environments. $21 \%$ of the Eastern Cape rural school in the sample and $22 \%$ the classroom environments are below the expected level. This shows that the learning environments in the schools need to be developed.

Figure 2 shows the support from the Government to ensure quality education to the rural schools as per the students.

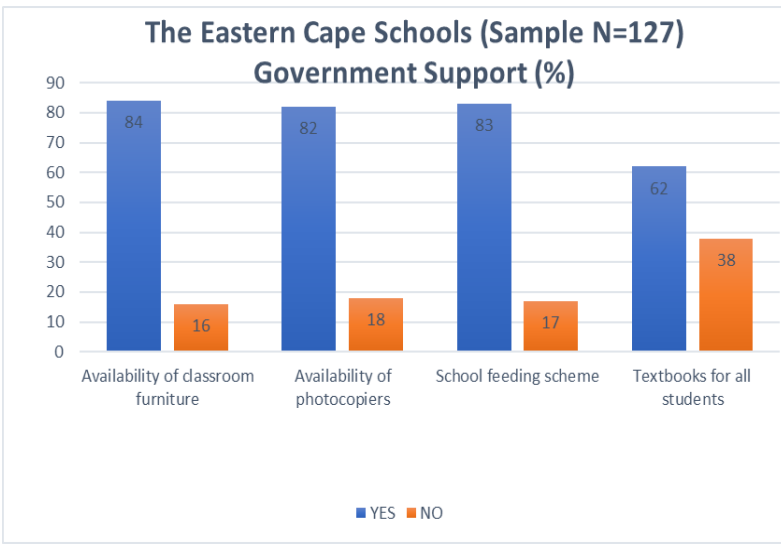

Figure 2. The support from Government in 127 Eastern Cape Schools as per students' response

Figure 2 shows that majority of the schools are supplied with furniture, photocopiers, feeding scheme $(84 \%, 82 \%$ and $83 \%$ respectively), which is commendable. Only $62 \%$ schools are supplied with textbooks and the lack textbooks (38\%) is of a great concern.

Figure 3 shows the use of ICTs in the Eastern Cape classrooms. In the response to whether the learning environments are ready with ICT implemented teaching and learning, $67 \%$ of schools seem to be non-compliant.

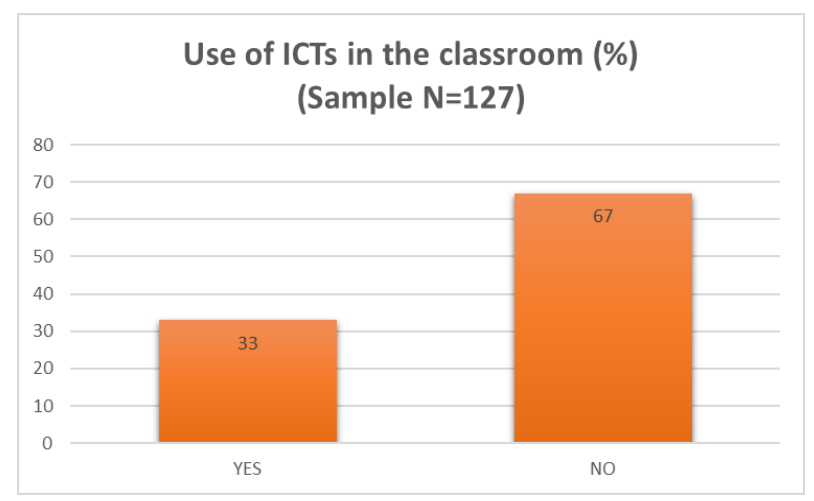

Figure 3. The use of ICT in 127 Eastern Cape Schools as per students' response

The data from the students indicate that the majority of schools have the requisite learning environment, but ICT 
usage is still a long way off. Out of the 127 schools in the sample, $67 \%$ of the schools do not use ICTs. This shows that the learning environment is far from ready with ICT implementation for sustainability. For data triangulation, data from 21 teachers teaching in different rural schools are presented below. The teachers might not all be necessarily from the same schools where the students come from, but there is strong possibility that some schools might be the same as all the teachers in the sample $(\mathrm{N}=21)$ are part of the 127 rural schools in the province.

\subsubsection{Analysis of the data from the rural school teachers}

The data from the 21 rural school teachers' anonymous survey was tabulated using Microsoft Excel 2013. The biographical information is shown in Table 1.

Table 1. Biographical information of rural school teachers

\begin{tabular}{|c|c|c|c|}
\hline $\begin{array}{c}\text { Biographical } \\
\text { information }\end{array}$ & $\begin{array}{l}\text { Criteria/ } \\
\text { interval }\end{array}$ & $\begin{array}{c}\begin{array}{c}\text { Number } \\
(\mathrm{N}=\mathbf{2 1})\end{array} \\
\end{array}$ & Percentage \\
\hline \multirow{2}{*}{ Gender } & Male & 7 & $33 \%$ \\
\hline & Female & 14 & $67 \%$ \\
\hline \multirow{4}{*}{ Age group } & $25-29$ Years & 1 & $5 \%$ \\
\hline & $30-39$ Years & 7 & $33 \%$ \\
\hline & $40-49$ Years & 12 & $57 \%$ \\
\hline & $50-59$ Years & 1 & $5 \%$ \\
\hline \multirow{3}{*}{$\begin{array}{c}\text { Educational } \\
\text { Qualification }\end{array}$} & $\begin{array}{c}\text { Bachelors' } \\
\text { Degree }\end{array}$ & 8 & $38 \%$ \\
\hline & Honors' Degree & 6 & $29 \%$ \\
\hline & Masters' Degree & 7 & $33 \%$ \\
\hline \multirow{4}{*}{$\begin{array}{c}\text { Teaching } \\
\text { Experience }\end{array}$} & $0-4$ Years & 5 & $23 \%$ \\
\hline & $5-9$ Years & 6 & $29 \%$ \\
\hline & $10-19$ Years & 6 & $29 \%$ \\
\hline & $20-29$ Years & 4 & $19 \%$ \\
\hline
\end{tabular}

Most of the teachers $(90 \%)$ are middle-aged teachers (30-49 Years) and $38 \%$ of the teachers have a first-degree educational qualification (Bachelors' Degree). Most of them $(77 \%)$ have teaching experience of more than five years, of which $19 \%$ of them have more than 20 years of teaching experience.

\section{Rural School Teachers' availability and use of ICTs ( $\mathrm{N}=\mathbf{2 1}$ )}

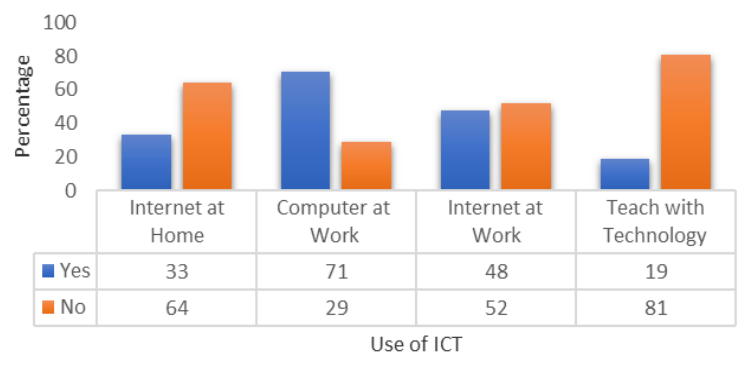

Figure 4. Rural school Teachers' availability and use of ICTs
The teachers were further asked to indicate whether they have internet at home, computer and internet at work and whether they teach with digital technology. Figure 4 gives the analysis of the data from the 21 teachers from the rural schools.

From Figure 4, it is evident that the majority of teachers does not have internet access at home and at work as $64 \%$ of them indicated that they do not have internet at home, while $52 \%$ indicated that they do not have internet at their schools. Although $71 \%$ of teachers indicated that they have computers at work, only $19 \%$ of them teach with technology. In response to further items on the type of internet at school, $48 \%$ teachers indicated that they have internet at school, of which $70 \%$ teachers are connected by $\mathrm{Wi}-\mathrm{Fi}, 20 \%$ teachers have network cables, and $10 \%$ teachers have data routers to get connected to internet facilities. The teachers also noted that most of the internet availability is confined only in the offices of the administration. The non-availability of internet in the classrooms might be the reason that even the schools with computers cannot integrate it for teaching purposes. The four teachers $(19 \%)$ who teach with technology further indicated that only two of them use it to access on-line materials for teaching. One teacher mentioned that there is internet access and digital tools in the classroom. But, as indicated, she does not teach with technology.

The data from the teachers pose a serious concern. All 21 teachers are qualified teachers with at least a bachelor's degree. Majority of the teachers are middle aged teachers $(90 \%) .71 \%$ of the teachers have computers at work, $48 \%$ have internet facilities at work, but only $19 \%$ of them use ICTs in their teaching. The teachers were further asked on the most used digital tool at home of which, only three out of the 21 teachers indicated that they have laptops at home, which adds to the reality that they are not familiar with using the technology at home. Most university bachelor's degree courses in South African universities teach basic computer literacy programmes and all the teachers in the sample have indicated that they are graduates. But the use of ICTs is not implemented in most classrooms. This sheds light to the fact that serious investments are to be done in two major aspects: networking the classrooms with internet facilities and equipping the teachers for ICT implementation in the classrooms. Then only can sustainable learning environments in the rural schools be comprehended in the context of 4IR in South Africa.

\subsubsection{Reports on school education and ICT Usage in South Africa}

Post-apartheid South Africa has invested much of its revenue into education anticipating that providing quality education will eradicate poverty and the social ills of the past [11]. For this reason, relevant documents regarding policies and reports on ICT integration and sustainable development were used in this study. As mentioned in the 
methodology, these documents were analysed to shed light on the vision and planning of creation of sustainable learning and ICT integrated teaching environments in the rural education contexts.

The National Planning Commission (NPC) [11] reports that even after 18 years (in 2012) into democracy, South Africa continues to be an incredibly unequal country, with too many people living in poverty, too few people working, and most black learners receiving inadequate education. South Africa's ICT infrastructure is appalling in comparison with international standards. A stronger broadband and telecommunications network as well as lower prices, are needed for an efficient information infrastructure that stimulates monetary growth and greater inclusion [11]. The NPC [11] recommended to aim for no-fee schools in rural areas; when scheduling infrastructure, to reward for resource discrepancies in societies. The NPC [11] calls for well-equipped libraries, laboratories, computer and media centres to ensure that learners in no-fee schools have access to similar learning resources to their counterparts in less poor societies. High-speed broadband should be readily accessible and integrated into the design of schools. This will support more use of technology in schooling and augment the classroom experience for both students and teachers [11]. The report also envisioned for the strengthening of professional development, school infrastructure, provision of teacher support systems and learner support materials. Data from this study suggest that a few of these visions have materialised, but the abysmal ICT infrastructure situation is still persistent in rural schools of Eastern Cape Province.

The NECT Technical Report [6] mentions that integrative provincial strategies are not clear, and improvement is disjointed and driven by solution providers. The report points out that significant room for improvement exists in the schooling system, system-wide change management needs to be prioritized, and ICT-enabled evaluation must be considered. The NCET report [6] further indicates that the capacity of the schooling system to implement ICTs in support of schooling must be built for long-term sustainability, and the focus should move from learner success to capacity advancement. Data from the present study suggests that the situation remains unchanged in the rural education communities of the Eastern Cape and that capacity development in ICT integration of rural teachers is to be prioritised. This also calls for strengthening the teacher training programmes in the universities with increased ICT integrated opportunities.

\section{Discussion}

To address the two research questions, data from three different sources were analysed. They shed light on the type of learning environment available in the schools in Eastern Cape and pointed out that these learning environments are not ready for ICT implementation for sustainability or to gear them towards the 4IR.

The Discussion Forum [19] in their concept document on implications of the 4IR for science, engineering, and technology (SET); industry, society and education in South Africa; envisage that the schools, colleges, universities or private institutions' future classroom will be very different from what earlier generation knew, with the move across to digital on-line teaching and knowledge and information sharing via the Internet. The discussants envisaged that in the upcoming years, teachers need to be prepared with the essential ICT skills to employ e-education platforms and to go through routine ICT skills training. Teachers in the present study indicated that the majority of rural school teachers need to be trained in ICT skills in view of the reality that the 4IR is in our faces. By doing so, most teachers will meet the expectations of young adults as they transition from education to the world of work [20]. This study also supports the idea by Salehi and Salehi [21] that observing the hindrances for using ICT in schools can assist the educators to overcome the hindrances and incorporate ICT in daily education. The author also concurs with Padayachee [22], who observed that ICT integration in South African schools has been relentlessly inadequate due to operational, pedagogic and strategic challenges. Oke, Araujo, and Fernandes [12] also opine that to leverage the technologies associated with 4IR to improve learners' experiences, education curricula will need to be significantly improved, as well as investments.

The data from students and the documents seem to suggest that even though most rural schools in the sample have received the kind of support from the government as mentioned in the NPC [11] report in terms of furniture, resources, ICT equipment and feeding schemes, which are conducive enough to create a sustainable learning environment. However, teachers do not seem to be integrating ICT in their classroom teaching. Lippman [17] points out that, if technology is to be completely integrated into educational settings, the culture that already exists in institutions (schools) must be transformed.

In Egypt, students have endured deterioration of education quality in the present because of learning spaces deficiency, a large number of students in class, inadequate governmental funding, and disbursement [3]. The above authors posit that the classroom is the fundamental unit of the scholastic environment for a learner and his physical and emotional state, and the classroom environment should stimulate learning in a positive manner. However, as pointed out by Elseragy et al. [3], in Egypt, the classroom, away from theoretically showered models, is much punitive and poorer in its larger sphere of activity and, because of that, efficacious sumptuous models would 
fail, not because of their own fault. In an instructional environment where computers and such equipment are scarce, and if found, are costly and actually not put to any use. A similar situation is portrayed in the rural Eastern Cape schools through data obtained from students and from teachers, emanating from the NPC [11] report on the transition from apartheid to democracy.

The White Paper on e-Education [4] points out that the ICT revolution influenced curriculum development and implementation, and it continues to pose (new) challenges to education and training systems around the world. According to the above report, challenges include involvement in the knowledge society, the impact of ICTs on access, cost effectiveness, quality of education, and the lack of incorporation of ICTs into schooling. Even after 16 years, the data from the study seem to suggest that this is a persistent challenge for many rural schools in South Africa.

Weiss [23], cited in Lippman, [17] reports that computers, laptops, and smart boards have also been used in classrooms in the United States. Nonetheless, none of these previous or current innovations have been completely integrated into educational programs, as planned. Brecko, Kampylis and Punie [1] also talk of a situation in Europe, where there is also growing dissatisfaction and perplexity as to why, despite rapid technological advancements and the widespread use of ICT at home and in schools, schooling has not changed in any significant way. A similar situation is also noted by Tonui, Kerich and Koross [24] in Kenya where many teachers in their study acknowledged that ICT has great prospects to augment learning activities, but it is hindered by challenges such as insufficient equipment, deficiency in technical and administrative support, unsuitable attitudes and insufficient training. It is noted that computer access and other types of technology have risen significantly in recent years, but the amount of classroom use in Eastern Cape Province's rural schools has not kept pace with this substantial increase. Even though students and teachers are aware of the immense possibilities, insufficient technical support, little access to internet, shortage of class time and high cost of ICT facilities are the reasons specified for the non-integration of ICTs in the sampled schools.

The same effect as a textbook is achieved by providing electronic access to learning material (e.g., by tablets that can access data from a local server). Nonetheless, in the absence of a teacher who guides students through the process of memorizing facts to applying those facts to create new information, such technical intervention will usually yield insufficient results [6]. The author of this paper also concurs with Weiss [23], cited in Lippman, [17] that the ICTs are currently not designed for any particular pedagogy, but are expected to be integrated into any and all educational settings. The Eastern Cape Department of Basic Education (DBE) needs to address this issue urgently, as resources have not been used for its anticipated purpose. South African government also needs to put forward such a vision exclusively for rural schools, especially for Eastern Cape, which is the hardest hit with lack of development.

Although the NPC report [11] calls for exposing and preparing teachers to use technology in their own training and in their teaching, data sources from students and rural school teachers infer that the non-usage of ICTs in the classroom can be attributed to the encounters and obstructions confronted by the teachers themselves irrespective of the resources provided to them. It is also noted by Dube, Nhamo and Magonde [25] that universities might be causative to this ICT fright by not preparing teachers sufficiently for using ICTs. The author of this paper, a trained teacher, and a teacher trainer, suggests that teachers have to be trained in using ICT in their own classrooms. Solemn investments are needed for capacity development of in-service teachers and more ICT integrated teaching and exposure to pre-service teacher training. The key points that need to be stressed to the teachers are: ICTs offer new ways of teaching the same thing, it enables a focus on every child's needs, it saves time in lesson planning and administration, it offers a more comprehensive approach to assessment and reduces time on paperwork. If this can be transpired through our teacher education courses, it can be expected that the newly graduated teachers may use it in their classrooms.

The NPC Report [11] suggests that better use of technology aided by high-speed broadband could open doors for marginalized school learners which are not currently accessible. The report calls for the Department of Basic Education (DBE), Department of Communications and Department of Public Enterprises, to devise a combined plan to roll out broadband ICT setups to schools. The author also supports this call as no rural school learner should be left behind in the context of 4IR.

System-wide transformation management is required to be put in place and ICT-enabled assessment needs attention [6]. Human progress is initiated by global connectivity. ICTs are the core of the digital economy as it enhances the efficiency and productivity of both the teaching and learning. Teachers, being part of a connected and wired world, need to learn how to take advantage of those connections and opportunities to help students achieve their goals. Ojo and Adu [26] note that the high schools in South Africa that do not use ICTs in teaching and learning have resulted in the country's failure to achieve recent scholastic development and progress. The innovative potential of ICT in education can only be realized if it is combined with the necessary pedagogical and institutional changes [27].

A 21st century instructional setting designed to create an engaging learning environment is thought to attract active learners. As Elseragy et al. [3] put it, it might be difficult to implement the rollout of ICTs in most rural 
societies, but it is imperious to discourse present environments and find appropriate solutions which will ultimately aim a sustainable ICT integrated learning environment.

\section{Conclusions}

In South Africa, it can be concluded that, even though ICTs in education is a most talked-about topic, it is the least implemented in rural contexts as seen in the sample from the rural province under review. It is noted that computer access and other types of technology have increased significantly in South Africa, but classroom use has not increased in unison. ICT-enabled contexts in the school that a rural school learner experiences and which support academic achievement, should be improved. This calls for all stakeholders to remove most barriers to ICT implementation. Serious investments are to be done in two major aspects of rural school education in terms of infrastructure and skills development such as networking the classrooms with internet facilities and equipping the teachers for ICT implementation in the classrooms. Qualified academics and ICT professionals should get involved with the policy formation, teacher training and curriculum development processes. Pre-service teacher training also needs to be strengthened with more ICT integrated experiences. ICT-enabled sustainable learning environments in which rural school learners can experience the benefits, which can thus be improved. This in turn will gear rural societies towards the 4th Industrial Revolution.

\section{REFERENCES}

[1] Brecko, B. N., Kampylis, P. \& Punie, Y. (2014). Mainstreaming ICT-enabled Innovation in Education and Training in Europe: Policy actions for sustainability, scalability and impact at system level. JRC Scientific and Policy Reports. Seville: JRC-IPTS. doi:10.2788/52088

[2] UNICEF (2016). Quality Education: Why it Matters. Retrieved March 25, 2017 from http://www.un.org/sustaina bledevelopment /education.

[3] Elseragy, A., Elnokaly, A., \& Gabr, M. (2011). Building Sustainable Learning Environments that are 'Fit for the Future' with Reference to Egypt. World Sustainable Building Conference, Helsinki, Finland, At Helsinki, Finland, Volume: Proceedings of the World Sustainable Building Conference, Volume 2, Helsinki, (456-62), Finland.

[4] Department of Basic Education, RSA. (2004). Government Gazette, Vol. 470, Pretoria 26 August 2004, No. 26734: White paper on e-Education: Transforming learning and teaching through information and communication technologies (ICTs). https://www.gov.za/sites/default/files/g cis_document/201409/267341.pdf
[5] World Economic Forum (2016). The Fourth Industrial Revolution: what it means, how to respond. Retrieved May 28, 2019 from https://www.weforum.org/agenda/2016/ 01/the-fourth-indusial-revolution-what-it-means-and-how-to -respond/

[6] National Education Collaboration Trust (2016). The state of ICT in Education in South Africa. Retrieved August 20, 2019 from http://nect.org.za/publications/technical-reports/t he-state-of-ict-in-education-in-south-africa/

[7] Noor-Ul-Amin, S. (2018). An Effective use of ICT for Education and Learning by Drawing on Worldwide Knowledge, Research, and Experience: ICT as a Change Agent for Education. Retrieved May 25, 2018 from http://www.nyu.edu/classes/keefer/waoe/amins.pdf

[8] Yusuf, M.O. (2005). Information and communication education: Analyzing the Nigerian national policy for information technology. International Education Journal Vol. 6 No. (3), Pp; 316-321. https://www.researchgate.net/public ation/228615696.

[9] Fernando, M., \& Ekanayake, M.B. (2018). Sustainable Quality Improvement of ICT Education in the Secondary School for developing countries through the Sri Lankan experience. Retrieved November 23, 2019 from https://www.researchgate.net/publication/328289862

[10] Moodly, A.L., \& Adu, E.O. (2014). Information and Communication Technology (ICT)in Education for Sustainable Development (ESD): Quality Teaching and Learning Outcomes. Journal of Communication, 5(2): 197-202.

[11]National Planning Commission (2012). Executive Summary-National Development Plan 2030 - Our future make it work [PDF], 15 August 2012 NATIONAL DEVELOPMENT PLAN - 2030. Retrieved August 20, 2019 from http://www.gov.za/sites/www.gov.za/files/Execu tive $\% 20$ Summary-NDP $\% 202030 \% 20 \% 20$ Our $\% 20$ future $\% 2$ 0-\%20make\%20it\%20work.pdf

[12] Oke, A., Araujo, F., \& Fernandes, P. (2020). Innovations in Teaching and Learning: Exploring the Perceptions of the Education Sector on the 4th Industrial Revolution (4IR) Open Innov. Technol. Mark. Complex. 2020, 6, 31; doi:10.3390/joitmc6020031 www.mdpi.com/journal/joitmc.

[13] Brundtland, G. H. (1987). World commission on environment and development, our common future. Comissão Mundial.

[14] Sustainable Development (2015). Advocacy toolkit Mini-Site. https://www.sustainabledevelopment2015.org/AdvocacyTo olkit/index.php/earth-summit-history/historical-documents/9 2-our-common-future

[15] Sachs, J.D. (2015). The Age of Sustainable Development. Columbia University Press, Columbia. https://doi.org/10.10 80/01944363.2015.1077080

[16] Alanazi, S. (2016). Comparison for Curriculum Ideologies. American Research Journal of Humanities and Social Sciences, Volume 2, 2016; pp:1-10. https://doi.org/10.1007/ s41297-019-00089-X

[17] Lippman, P.C. (2010). Can the physical environment have an impact on the learning environment? CELE Exchange 
2010/13 (C) OECD 2010. Retrieved August 20, 2019 from https://www.oecd-ilibrary.org/can-the-physical-environment -have-an-impact-on-the-learning-environment_5km4g21wp wr1.pdf

[18] Dzansi, D.Y., \& Amedzo, K. (2014). Integrating ICT into Rural South African Schools: Possible Solutions for Challenges, International Journal of Educational Sciences, 6:2, 341-348, DOI: 10.1080/09751122.2014.11890145.

[19] Discussion Forum (2018). The 4th Industrial Revolution Concept Document: Implications of the 4th Industrial Revolution for SET, industry, society, and education: South Africa.

[20] OECD (2019). Effective Learning Environments: Analytical Framework for Case Study Collection. Retrieved August 20, 2019 from http://www.oecd.org/education/effect ive-learning-environments/Analytical-Framework-for-CaseStudy-Collection.pdf

[21] Salehi, H., \& Salehi, Z. (2012). Challenges for Using ICT in Education: Teachers' Insights. International Journal of e-Education, e-Business, e-Management and e-Learning, Vol. 2, No. 1, February 2012.

[22] Padayachee, K. (2017). A Snapshot Survey of ICT Integration in South African Schools. South African Computer Journal 29(2), 36-65. Retrieved April 5, 2020 from https://doi.org/10.18489/sacj.v29i2.463

[23] Weiss, A. (2007). "Creating the Ubiquitous Classroom: Integrating Physical and Virtual Learning Spaces, in The International Journal of Learning, Vol. 14, No. 3, www.Learning-Journal.com.
https://doi.org/10.18848/1447-9494/CGP/v14i03/45256

[24] Tonui, B., Kerich, E., \& Koross, R. (2016). An Investigation into Implementation of ICT in Primary Schools, in Kenya, in the Light of Free Laptops at Primary One A Case Study of Teachers Implementing ICT into Their Teaching Practice. Journal of Education and Practice, Vol.7, No.13, 2016. Retrieved April 5, 2020 from https://files.eric.ed.gov/fulltex t/EJ1102802.pdf

[25] Dube, B.A., Nhamo, E., \& Magonde, S. (2018). Factors affecting ICT integration in the Teaching and Learning of Physical Education in South Africa: A Case of Johannesburg East Cluster Primary Schools in the Gauteng Province. International Journal of Sport, Exercise and Health Research. 2. 88-92. 10.31254/sportmed.2103. https://www.researchgate.net/deref/http\%3A\%2F\%2Fdx.doi .org\%2F10.31254\%2Fsportmed.2103

[26] Ojo, O.A., \& Adu, E. O. (2018). The effectiveness of Information and Communication Technologies (ICTs) in teaching and learning in high schools in Eastern Cape Province South African Journal of Education, Volume 38, Supplement 2, December 2018 S1 Art. \#1483, 11. Retrieved April 5, 2020 from https://doi.org/10.15700/saje.v38ns2a14 83

[27] Kampylis, P., Bocconi, S., \& Punie, Y. (2012). Towards a mapping framework of ICT-enabled innovation for learning. Luxembourg: Publications Office of the European Union. EUR 25445. EN. Retrieved August 20, 2019 from http://tinyurl.com/d5wn6lb. https://www.researchgate.net/deref/http $\% 3 \mathrm{~A} \% 2 \mathrm{~F} \% 2 \mathrm{Fdx}$.doi .org\%2F10.2791\%2F89492 